\begin{abstract}
Female leaders remain a minority. Because leadership aspiration is a predictor of advancement, understanding stimulating conditions is important. A neglected perspective is the impact of organizational climate. We propose that cooperative climate can engender individuals' motivation to contribute to the organization through leadership, and that leadership aspiration of women and men is differentially sensitive to interpersonal and collective aspects of cooperative climate. We argue that women are more disposed towards relational self-construal and men towards collective self-construal, and hence women's leadership aspiration is more influenced by the interpersonal element of cooperative climate whereas men's leadership aspiration by the collective element of cooperative climate. Results of a survey of $N=404$ employed men and women supported both hypotheses.
\end{abstract}

Keywords: gender, leadership aspiration, cooperative climate, self-construal 
Gender and Leadership Aspiration: Interpersonal and Collective Elements of Cooperative Climate Differentially Influence Women and Men

Today's employment market remains characterized by gender inequality. Although more than $60 \%$ of all women aged 20-64 within the EU are employed (Eurostats, 2014), only 7\% of all CEOs within major listed EU companies are female (European Commission, 2015). There is a complex of factors involved in the lower representation of women in leadership positions (Eagly \& Carli, 2003; Eagly \& Karau, 2002; Heilman, 2001). Here we focus on one aspect of the issue that tends to be underrepresented in the study of gender and leadership: women's leadership aspiration. Examining leadership aspiration, the interest in attaining a (higher) leadership position (Singer, 1991), is of importance because leadership aspiration is linked to career attainment (Schoon \& Polek, 2011), occupational status (Schoon, Martin, \& Ross, 2007), and hierarchical advancement (Tharenou, 2001).

Meta-analytic evidence indicates that men have higher motivation to manage than women (Eagly, Karau, Miner, \& Johnson, 1994), and that men value power and leadership more (Konrad, Ritchie, Lieb, \& Corrigall, 2000). Within primary research there obviously is also evidence reflecting these meta-analytic conclusions (Cooke \& Xiao, 2014; Hoobler, Lemmon, \& Wayne, 2014; Savery, 1990; van Vianen \& Keizer, 1996), but not consistently so. Other primary studies found no evidence of gender differences in leadership aspiration or related constructs (Chan \& Drasgow, 2001; Gbadamosi, Evans, Richardson, \& Ridolofo, 2015; Morrison, White, \& Velsor, 1987; Singer, 1991). Such null findings do not challenge meta-analytic conclusions, but they do point to the possibility that gender differences in leadership aspiration may not universally exist, and that a contingency approach to such differences may be called for. Such a contingency perspective is especially important to develop because it may point to ways in which female leadership aspiration can be stimulated. Gender and leadership scholars focused on a variety of barriers to obtaining leadership 
positions for women that may discourage leadership aspiration. These barriers are mostly associated with the work-life interface (Cross, 2010; Ezzedeen, Budworth, \& Baker, 2015; Killeen, López-Zafra, \& Eagly, 2006; Lips, 2000, 2001). Barriers to female leadership also include various conditions within the organizational environment, such as difficulty to find a mentor (Athey, Avery, \& Zemsky, 2000; Ragins \& Cotton, 1991), fewer high status contacts (Ibarra, 1997; McGuire, 2000) and less organizational support (Burke, 2002; Pachulicz, Schmitt, \& Kuljanin, 2008). Women are confronted with an organizational environment with more men in senior positions - currently, two-thirds of all managers are men (Eurostat, 2015). Because men perceive leadership more in masculine terms than women (Koenig, Eagly, Mitchell, \& Ristikari, 2011), this may yield additional barriers for female leadership attainment (Eagly \& Karau, 2002). All of these organizational conditions depict relevant barriers for women that may discourage female leadership aspiration.

Our own conceptual model starts with the observation that there seems to be a gap in the literature in terms of an underdeveloped understanding how the organizational environment may actually stimulate women's leadership aspiration rather than merely remove barriers to leadership. The organizational climate construct was specifically developed to capture social influences of the organizational environment, where climate is defined as "the meanings people attach to interrelated bundles of experiences they have at work" (Schneider, Ehrhart, \& Macey, 2013, p. 361). Climate can be understood with different emphases, and we propose that the extent to which a climate is cooperative, supportive, and characterized by team spirit (Fisher, 2014; Koys \& DeCotiis, 1991), is particularly relevant to the issue of gender and leadership aspiration. Leadership, and thus also leadership aspiration, is closely tied in with the motivation to collaboratively pursue team and organizational objectives (van Knippenberg, van Knippenberg, De Cremer, \& Hogg, 2004). Cooperative climate may provide the context to foster such motivation. 
Cooperative climate is linked to positive outcomes, such as more social interaction (Chen \& Huang, 2007), and greater willingness to share materials, information, or knowledge (Hammami, Amara, \& Landry, 2013; Llopis Córcoles, \& Foss, 2012). All of these behaviors benefiting the organization can be regarded as prosocial behaviors. Because the work context impacts prosocial motivation (Grant, 2007, 2009), cooperative climate is not only expected to foster prosocial behavior but also prosocial motivation. Prosocial motivation is defined as an orientation towards joint successes and communal welfare (De Dreu, Nijstad, \& van Knippenberg, 2008; Grant, 2007; Grant \& Berry, 2011). In reference to this prosocial motivation, cooperative climate is expected to also be linked to this motivation, to the will "to go the extra mile for the organization" (Kuvaas \& Dysvik, 2010, p. 6). We therefore expect that cooperative climate also impacts leadership aspiration, because leadership itself involves the prosocial motivation to motivate others to pursue collective objectives (Bass \& Stogdill, 1990; Burns, 1978).

Because there are gender differences in the disposition to different self-construals (Baumeister \& Sommer, 1997; Cross \& Madson, 1997; Cross, Bacon, \& Morris, 2000; Gabriel \& Gardner, 1999), we predict that men and women are differentially sensitive to different cooperative climate elements. Because women tend to be more oriented towards close relationships (Cross \& Madson, 1997; Cross et al., 2000; Gabriel \& Gardner, 1999), we propose they are more sensitive to those elements of cooperative climate that revolve around interpersonal relationships. In contrast, men tend to be more oriented towards larger groups (Baumeister \& Sommer, 1997; Gabriel \& Gardner, 1999) and as a result they are expected to be more sensitive to those aspects of cooperative climate that emphasize the collective, the overarching community.

Such elements can occur simultaneously within an organization. Yet, as observed by for instance Zohar and Luria (2005) as well as by Merkys, Kalinauskaitė, Beniušienè, Veinhardt, 
and Dromantas, (2005), climate can differ independently to some extent between different foci. To measure climate, scholars have employed various conceptualizations and operationalizations (e.g., Brown \& Leigh, 1996; Coda, da Silva, \& Custodio, 2015; Koys \& DeCotiis, 1991; Patterson et al., 2005; Thumin \& Thumin, 2011). We propose that from the perspective of gender differences in self-construal, the most relevant distinction in relation to gender and leadership aspiration is between relationally and collectively oriented elements of cooperative climate.

The contribution of our study lies in emphasizing that the organizational environment may not only discourage but also stimulate women's leadership aspiration - and that these climate influences differentially affect women's and men's leadership aspiration. From a theoretical angle, these insights are important because they help to extend our knowledge of how women's (and men's) leadership aspiration can be fostered by the organizational environment. Also for practice they are relevant because climate is "relatively temporary, subject to direct control"' (Denison, 1996, p. 624), and can thus be promoted and improved actively to increase women's leadership aspiration.

Within the following, we first provide an overview of the literature and propose two hypotheses regarding the impact on women's and men's leadership aspiration of two different cooperative climate elements. Then, our empirical work is presented and discussed. Finally, we outline the theoretical as well as practical implications of our research and conclude with a limitations, future research, and conclusion section.

\section{Organizational Climate}

Within the literature focused on the work environment, organizational climate has received considerable attention. Organizational climate, reflecting "perceptions of organizational policies, practices, and procedures that may influence the attitudes, perceptions and subsequent behavior" (Fletcher \& Nusbaum, 2009, p. 2), can have different 
configurations. These can range from a competitive climate in which there is competition among coworkers for tangible and intangible rewards (Arnold, Flaherty, Voss, \& Mowen, 2009; Fletcher \& Nusbaum, 2009; Kohn, 1992; Sahadev, Seshanna, \& Purani, 2014) to a cooperative climate in which employees collaborate with each other and share and generate knowledge (Chen \& Huang, 2007, Janz \& Prasarnphanich, 2003). Cooperative climate "is more relevant to organizational performance than the physical work environment" (Tsai, Horng, Liu, \& Hu, 2015, p. 26). Cooperative climate has been shown to be linked to commitment (Bogaert, Boone, \& van Witteloostuijn, 2012; Fisher, 2014), social interaction (Chen \& Huang, 2007), and knowledge sharing (Hammami et al., 2013; Llopis et al., 2012). In addition, meta-analyses, taking a broader conceptualization that includes but is not limited to cooperative climate, show a positive relationship between climate and organizational commitment (Arora, Nuseir, Nusair, \& Arora, 2012; Carr, Schmidt, Ford, \& DeShon, 2003).

These outcomes of cooperative climate are likely to be informed by prosocial motivation, which is characterized by the willingness to strive for shared successes (De Dreu et al., 2008, Grant, 2007; Grant \& Berry, 2011). Because leadership is often focused on engendering prosocial motivation of followers to strive for such shared successes (Bass \& Stogdill, 1990; Burns, 1978), we expect that cooperative climate, fostering prosocial motivation, also impacts the aspiration to become a leader. Because women and men are disposed to different self-construals (i.e., relational vs. collective), we also predict that they are more sensitive to different elements of cooperative climate. In the following, we elaborate on these gender differences.

\section{Gender and cooperative interpersonal climate}

Women more than men are disposed to hold self-views that capture close relationships with others (Cross \& Madson, 1997; Cross et al., 2000, Gabriel \& Gardner, 1999). Put differently, "women's sociality is oriented toward dyadic close relationships" (Baumeister \& 
Sommer, 1997, p. 38). Employees tend to have frequent interactions and a multitude of required work-related exchanges with coworkers (Chiaburu \& Harrison, 2008; Ferris \& Michell, 1987; cf. van Knippenberg \& van Schie, 2000). Coworkers thus constitute an important source of close relationships at work.

Coworker relationships are linked to various positive aspects, such as increased job satisfaction (Ducharme \& Martin, 2000; Simon, Judge, \& Halvorsen-Ganepola, 2010), reduced emotional exhaustion (Ducharme, Knudsen, \& Roman, 2008; van Emmerik, 2002), and a decreased intention to leave (Ducharme et al., 2008; Regts \& Molleman, 2013). Basford and Offermann (2012) further showed a positive link between supportive relationships among coworkers and employee motivation. Such supportive relationships among coworkers, or put differently, cooperative interpersonal climate, are not only expected to increase employee motivation but to speak directly to the relational motives women are more sensitive to than men. Because we predict, as discussed before, that cooperative climate elements map onto gender-contingent self-construal and thus have an influence on leadership aspiration, we expect cooperative interpersonal climate to be associated with women's leadership aspiration. In line with meta-analytic evidence indicating that women more than men generally "prefer jobs that provide opportunities to work with people and help others" (Eagly \& Carli, 2007, p. 60), we predict that cooperative interpersonal climate is more strongly (positively) related to women's leadership aspiration than to men's leadership aspiration.

Hypothesis 1: Cooperative interpersonal climate has a positive influence on leadership aspiration that is stronger for women than for men.

\section{Gender and cooperative collective climate}

Meta-analytic evidence shows that men have a greater desire for leadership and power (Konrad et al., 2000). Whereas such a desire is not necessarily informed by prosocial motives, it is important to note that a quest for power can be regarded as "a form of sociality rather 
than a quest for separation and independence” (Baumeister \& Sommer, 1997, p. 42). From that perspective, cooperative climate may also speak to men's leadership aspiration. Baumeister and Sommer (1997, p. 38) argued that men's sociality is “oriented more towards a larger group". Through various empirical studies, Gabriel and Gardner (1999) tested this proposition and showed that men indeed more than women tend to define themselves in collective terms (in terms of group membership; collective self-construal), whereas selfdefinition in terms of interpersonal relationships (relational self-construal) are more pronounced among women. In line with the rationale to expect cooperative interpersonal climate to be more strongly related to women's leadership aspiration, we may thus also predict that men's leadership aspiration more than women's is responsive to cooperative climate elements speaking to collective self-construal.

Hypothesis 2: Cooperative collective climate has a positive influence on leadership aspiration that is stronger for men than for women.

\section{Method}

For data collection we made use of an online survey, executed by a British online panel provider. Respondents had to fulfill specific criteria to be eligible for the survey, such as being full-time employed with a minimum of three years working and a minimum of one year job experience. In addition, they had to be working for a company with at least 20 employees in total. After having filled out the survey successfully, the online panel provided a small monetary incentive to the respondents according to its normal business operating model.

Online surveys are sometimes criticized for some points. Critics mention for example technological variations in the online survey's layout, potential classification by respondents as spam and a skewed population, e.g. mostly male respondents (Evans \& Mathur, 2005). However, in order to face these potential issues, some measures were taken. First and foremost we did readability and functionality tests in various browsers. Further, only the 
respondents who willingly opted-in to be part of the online panel were contacted so that it was not considered as spam. Finally, by defining certain quotas (i.e., a 50\% gender split) as well as minimum requirements (e.g., work and organizational experience), we are convinced that the sample is meaningful. In total, we believe that this online data's quality is adequate and not inferior to a traditional offline survey.

\section{Participants}

Overall, 404 respondents answered the survey. Of these 404 respondents, $50 \%$ were male and $50 \%$ were female. The respondents' age ranged from 22 to 65 years $(\mathrm{M}=44.93, \mathrm{SD}$ $=10.47)$. Their work experience ranged from the pre-defined minimum of 3 to a maximum of 50 years $(M=23.76, S D=11.66)$, their organizational experience ranged from 1 to 45 years $(M=11.60, S D=8.74)$ and their job experience ranged from the pre-defined minimum of 1 to 36 years $(\mathrm{M}=7.95, \mathrm{SD}=6.98)$. Their educational background was evenly split between a non-academic (49.5\%) and academic (50.5\%) background. To be more precise, $27.7 \%$ possessed a high-school degree as their highest education, $21.8 \%$ had done an apprenticeship, $34.9 \%$ hold a Bachelor and the remaining $15.6 \%$ hold a Master degree. The respondents had very diverse professional backgrounds, which were classified according to the International Standard Industrial Classifications of all economic activities (UN, 2015). The most represented professional backgrounds were manufacturing (12.6\%), health (11.4\%), education (10.9\%), other services (10.9\%), and public administration (9.9\%). All other professional backgrounds were only shared by less than 30 people, hence less than $7 \%$ of all respondents. The hierarchical background was evenly split between non-supervisory positions (50.7\%) and supervisory positions $(49.3 \%)$. Of the latter, $18.6 \%$ were first level managers, $23.5 \%$ were middle managers, $6.2 \%$ were within upper management and the remaining $2.5 \%$ were senior managers. Regarding the respondent's private life, $27.7 \%$ were single, $21.5 \%$ were in a relationship, and the remaining majority of $50.7 \%$ was married. Overall, $59.2 \%$ had children. 
The cultural background was relatively uniform as $90.8 \%$ were British, followed by $4.2 \%$ Continental European, 2.0\% Asian, 1.5\% African, 0.7\% American, and 0.7\% Australian (a detailed overview of participants' demographics, split by gender, can be found in the Appendix)

\section{Measures}

Leadership aspiration. The dependent variable leadership aspiration was measured by a 17 -item, 5 -point scale $(1=$ strongly disagree to $5=$ strongly agree $)$, measuring intentions and behaviors. In putting this measure together, we combined existing measures both from a desire to increase reliability by using a longer scale and from a desire to capture both behavioral intentions and behavior because these can both be indicative of aspirations.

To measure intentions, we employed the "leadership and achievement scale" initially developed by Gray and O'Brien (2007). In addition to their six items, we also used another three items in order to cater to Gray and O'Brien's suggestion to enlarge the scale. Sample items, such as "When I am established in my career, I would like to manage other employees", "When I am established in my career, I would like to train others" and "My aspirations for advancing in management positions are very high" were included in the scale measuring intentions. As mentioned above, we also measured behaviors, still self-reported, to have also more objective measures than intentions (Tharenou \& Terry, 1998). In order to measure behaviors, we were inspired by the work done by Day and Allen (2004), being adapted from London (1993) and Noe, Noe, and Bachhuber (1990) as well as Tharenou and Terry (1998). The second part of the scale, measuring behaviors, included items such as "I have sought feedback on my job performance", "I engaged in career path planning" or "I have requested to be considered for promotions".

Cooperative interpersonal climate. In order to measure cooperative interpersonal climate we used a 5-item, 5 -point scale ( $1=$ strongly disagree to $5=$ strongly agree $)$. The 
scale was initially developed by Koys and DeCotiis (1991) and was labelled "cohesion scale" measuring the interpersonal, relational aspects of the climate among employees. Sample items, such as "In the company I work for, people pitch in to help each other out" or "In the company I work for, people take personal interest in one another". Throughout the paper, we decided not to call it cohesion climate but rather cooperative interpersonal climate to render the term more expressive in terms of mapping this climate element to the greater female orientation towards interpersonal relationships.

Cooperative collective climate: To measure cooperative collective climate, we used a 4-item, 5 -point scale $(1=$ strongly disagree to $5=$ strongly agree $)$. The scale was initially developed by Patterson et al. (2005) and was labelled "welfare scale", being one of the distinct scales of the multidimensional organizational climate measure. It measures the climate between "the organization" and the individual, and thus collective aspects. Sample items, such as "This Company tries to look after its employees" or "This company cares about its employees" were part of the scale. Throughout the paper, we decided not to call it welfare climate but cooperative collective climate to make the term itself more expressive in terms of mapping this climate element to the greater male orientation towards the collective (see the Appendix for the full scales)

Gender. We included gender in the design as a predictor variable, as well as the gender by cooperative interpersonal climate and gender by cooperative collective climate interactions.

Control variables. In order to account for some heterogeneity in the sample, we also employed some control variables. Carlson and Wu (2001) argued that there needs to be a strong theoretical basis for including control variables. Accordingly, we selected three control variables. First and foremost, we controlled for hierarchical position. As Eagly \& Karau (2002) found that management position affects women's fit into leadership roles, we 
controlled for leadership position. The misfit between being female and being a leader "might be somewhat lower for middle manager" (Eagly \& Karau, 2002, p. 577). Thus, we dummycoded $1=$ middle manager, $0=$ other. Moreover, as we were interested to understand whether targets to increase the female ratio did not only have an impact on the actual number of women, but also an impact on leadership aspiration, we controlled for their existence. Therefore, we asked respondents whether the organization they worked for had specific targets to increase the number of female employees (e.g., quotas). We created a dummy variable with $1=$ existence of female targets, $0=$ unawareness of $/$ no existence of female targets. We also controlled for leadership self-efficacy because leadership self-efficacy may have an impact on leadership aspiration (cf. Gbadamosi et al., 2015; Singer, 1991; Hoyt, 2013; van Vianen \& Keizer, 1996; Yeagley, Subich, \& Tokar, 2010). We measured leadership self-efficacy with an 8 -item, 5 -point scale $(1=$ strongly disagree to $5=$ strongly agree $)$. The scale was initially developed by Murphy (1992) and included items such as "I know a lot more than most people about what it takes to be a good leader", and "I am confident of my ability to influence a group I lead".

\section{Results}

In the following, we discuss the results of the analyses. First, we focus on reliabilities and intercorrelations before discussing the regression analysis results. In Table 1 means, standard deviations as well as intercorrelations for all variables can be found. Additionally, also the reliabilities (Cronbach's $\alpha$ ) for the relevant scales are displayed in the same table. All scale reliabilities were good, ranging from 0.86 (leadership self-efficacy) to 0.96 (leadership aspiration), and additionally there were no overly high intercorrelations. We would also like to briefly discuss the intercorrelations between control variables and predictor variable as we are interested to understand whether there are also significant relationships apart from the ones with the dependent variable leadership aspiration. Hierarchical level did not have a 
significant correlation with any of the predictor variables (gender, cooperative interpersonal

climate, and cooperative collective climate). The existence of female targets however was

positively related to cooperative interpersonal climate. Self-efficacy was lower for women

and positively related to both types of cooperative climate. Even when we observe some

significant intercorrelations, it is important to note that these are all weak correlations: equal

to or less than $r=0.20$.

Leadership aspiration. In order to test our two hypotheses regarding the gender by cooperative interpersonal climate and the gender by cooperative collective climate interaction, we did a hierarchical regression analysis in which leadership aspiration was predicted by control variables (efficacy, hierarchical level and female targets) at step 1 and the main variables (gender, cooperative interpersonal climate, cooperative collective climate) at step 2. At step 3 both interaction terms were added (cooperative interpersonal climate $\mathrm{x}$ gender and cooperative collective climate x gender). Following Aiken and West (1991) cooperative interpersonal climate and cooperative collective climate were centered by subtracting the mean from each score. As a result, both main effect terms and the interaction terms were based on this centered score. Results are displayed in Table 2.

The $R^{2}$ of the model was .42 and significant $(p<.01)$. There was also a significant change at the $R^{2}$ from step 1 to step 2 of $.09(p<.01)$. Leadership self-efficacy $(b=0.60, \mathrm{SE}=$ $0.06, p<.01)$, hierarchical level $(b=0.27, \mathrm{SE}=0.09, p<.01)$ and female targets $(b=0.68$, $\mathrm{SE}=0.12, p<.01)$ were all positively related to leadership aspiration. These positive relationships are in line with previous research. Various scholars showed a positive impact of leadership self-efficacy on leadership aspiration and related constructs (cf. Gbadamosi et al., 2015; Singer, 1991; Hoyt, 2013; van Vianen \& Keizer, 1996; Yeagley, Subich, \& Tokar, 2010). Also with regards to hierarchical level our findings are in line with previous research, emphasizing that the misfit between being female and being a leader "might be somewhat 
lower for middle managers" (Eagly \& Karau, 2002, p. 577). Eventually, it is not surprising that female targets (such as e.g., quotas) have a positive halo-effect for leadership aspiration as respondents might feel that organizations try to promote leadership regardless of gender.

In contrast to these significant effects, we did not find a significant effect for gender $(b$ $=-0.06, \mathrm{SE}=0.07, p>.05)$. Hence, our results do not confirm that women have lower leadership aspiration than men. Although this does not negate meta-analytic findings of such differences, this is in line with other primary studies which did not show a main effect for gender and that were an important inspiration for the current interaction approach (Chan \& Drasgow, 2001; Gbadamosi et al., 2015; Morrison et al., 1987; Singer, 1991). With regards to the different climate types, our results show that whereas cooperative interpersonal climate $(b=0.10, \mathrm{SE}=0.06, p>.05)$ is not related to leadership aspiration as a main effect, cooperative collective climate is positively related to leadership aspiration $(b=$ $0.24, \mathrm{SE}=0.05, p<.01)$

Supporting Hypothesis 1, the interaction term of cooperative interpersonal climate $\mathrm{x}$ gender was significantly related to leadership aspiration $(b=0.21, \mathrm{SE}=0.11, p<.05)$. Following Aiken and West (1991), we subsequently executed a simple slope analysis to test the direction of the interaction term. The simple slope analysis showed that cooperative interpersonal climate was significantly positively related to women's leadership aspiration ( $b$ $=0.20, \mathrm{SE}=0.07, p<.01)$ while not being related to men's leadership aspiration $(b=-0.02$, $\mathrm{SE}=0.08, p>.05)$. We can thus conclude in line with our Hypothesis 1 , that cooperative interpersonal climate is more important for the leadership aspiration of women (cf. Figure 1 for visualization). Also Hypothesis 2 was supported as the interaction term of cooperative collective climate $\mathrm{x}$ gender was significantly related to leadership aspiration $(b=-0.20, \mathrm{SE}=$ $0.9, p<.05)$. Also in this case we conducted a simple slope analysis to test for the direction of the interaction term. The simple slope analysis showed that cooperative collective climate was 
significantly positively related to women's leadership aspiration $(b=0.14, \mathrm{SE}=0.06, p<.05)$ as well as to men's leadership aspiration $(b=0.34, \mathrm{SE}=0.06, p<.01)$. As the slope for men $(b=0.34)$ is steeper than the one for women $(b=0.14)$, we can conclude, in line with our Hypothesis 2, that cooperative collective climate is more important for the leadership aspiration of men (cf. Figure 2 for visualization).

\section{Discussion}

After having presented the results of our study, we now focus on both theoretical and practical implications before briefly discussing this study's limitations and directions of future research.

Lower leadership aspiration among women than among men may play a substantive role in gender differences in leadership attainment. We studied cooperative climate as a moderating influence in such gender differences. A focus on climate may not only increase our understanding of gender differences in leadership aspiration, but also yield actionable knowledge that may be translated to interventions to address such gender differences. In support of our conceptual analysis, our findings show that women's leadership aspiration is more strongly influenced by cooperative interpersonal climate, whereas men's leadership aspiration is more strongly influenced by cooperative collective climate. Although cooperative collective climate has a stronger influence on men's leadership aspiration, it also features a positive impact on female leadership aspiration. The fact that both types of cooperative climate feature a positive impact on female leadership aspiration may be due to the fact that women in general have a greater communal tendency (Bakan, 1966; Donnelly \& Twenge, 2016; Eagly, 1987; Feingold, 1994; Helgeson, 1994; Lyness \& Heilman, 2006). Therefore cooperative climate - also within the overall organizational context - being characterized by cooperation, support, and team spirit (Fisher, 2014; Koys \& DeCotiis, 1991), may also be something women are sensitive too in terms of their leadership aspirations even 
when this influence is stronger for men (cf. Carli, Alawa, Lee, Zhao, \& Kim, 2016; Gebauer

Paulhus, \& Neberich, 2013; 2013; Lyness \& Heilman, 2006). Cooperative interpersonal

climate on the contrary is only associated with women's leadership aspiration, yet unrelated to men's leadership aspiration. These findings have a number of theoretical and practical implications.

\section{Theoretical Implications}

Research on gender differences in leadership aspiration and leadership attainment has mostly focused on barriers to women's leadership attainment and their potentially discouraging influence on leadership aspiration (Carli \& Eagly, 2016; Eagly \& Carli, 2007; Hackett, \& Betz, 1981; Hoyt, 2010; Killeen et al., 2006; Rudman \& Glick, 2001; Rudman \& Phelan, 2010). It is hard to overstate the importance of this work. We would argue, however that the present perspective on organizational climate as an influence encouraging women's (and men's) leadership aspiration is an important counterpoint to the primary stream of research in the area. By identifying different elements of cooperative climate that differentially speak to women's and men's leadership aspiration we increase our understanding of gender differences in leadership aspiration in a way that also speaks to the practice of stimulating women's (and men's) leadership aspiration.

Climate is shaped by the interaction between people and the organizational context (Moran and Volkwein, 1992). A direct implication of our work thus is that organizational contexts that foster a cooperative interpersonal climate may stimulate women's leadership aspiration. This may include organizational practices such as team-based organization of the work, team building, and leadership focused on building and fostering cooperative interpersonal relations, but also cooperative collective climate as both types of climate are linked to female leadership aspiration. Leadership has been shown to be one decisive factor shaping organizational climate (Grojean, Resick, Dickson, \& Smith, 2004; Koene, Vogelaar, 
\& Soeters, 2002; Wang \& Rode, 2010). Rather than assuming that these implications also hold for cooperative climate, however, we would argue that they are valuable directions for future research to determine whether such influences indeed have the desired effect on women's leadership aspiration mediated by cooperative interpersonal climate. Such research would also be particularly important in bringing the insights from our analysis one step closer to actual interventions organizations may undertake to stimulate women's leadership aspiration.

Research on leadership and gender tends to treat leadership aspiration somewhat in the abstract, as if the key concern is a general aspiration for leadership independent of context. We believe that another important insight implied by our analysis is that leadership aspiration is at least in part bounded by context: it is the organizational climate that may encourage (or discourage) leadership aspiration - within the context of that organization. We should be careful not to draw too strong conclusions here because our study was not designed to contrast contextualized versus generic leadership aspiration, but this too would seem an insight worth following up on in future research. To a certain extent, leadership aspiration may be aspiration to lead within a particular organization rather than generic, and research in gender differences in leadership aspiration may have underestimated this contextual component so far. Because it is possible that the contextual component is stronger for women than for men - the latter may be more strongly driven by stereotype-based notions of male leadership (cf. Carli \& Eagly, 2016; Eagly \& Karau, 2002; Heilman, 2001; Lyness \& Heilman, 2006) - this may be a particularly worthwhile direction for future research developing our understanding of gender differences in leadership aspiration.

Future studied could further also examine the different cooperative climate elements from a social capital perspective. Social capital, being defined as the goodwill that is attributed to social relations and which can be employed to ease action, can either substitute 
or complement an individual's resources (Adler \& Kwon, 2002). Both perspectives are worthwhile to examine. From a substitution perspective, it would be important to assess whether cooperative climate within other interpersonal relationships, e.g., special female networks within an organization, could compensate for the absence of cooperative interpersonal climate among coworkers. Also looking at cooperative climate from a complementary perspective would be essential. Potentially, women who are exposed to a cooperative climate not only among their direct interpersonal relationships with day-to-day coworkers, but also within various other groups (e.g., project teams) or networks (e.g., special female networks) could potentially even more fruitfully use this climate element in terms of developing higher leadership aspiration.

Our analysis in terms of gender differences in self-construal suggest that future research may also be valuable in exploring the impact of social identifications on leadership aspiration. From the perspective of collective self-construal, organizational identification, defined as "the perceived oneness with an organization and the experience of the organization's successes and failures as one's own" (Mael \& Ashforth, 1992, p. 103), would be particularly relevant. Because men are more prone to collective self-construal (Baumeister \& Sommer, 1997; Gabriel \& Gardner, 1999), it is possible that men's leadership aspiration is also more driven by their level of organizational identification (i.e., as a "fit" with their disposition) than women's. Conversely, relational identification at work, self-definition in terms of salient and important interpersonal relations at work (Sluss \& Ashforth, 2007), may drive leadership aspiration for women more than for men; because women are more prone to relational selfconstrual, relational identification may be a better fit with their disposition. Based on the current findings, however, we may expect an asymmetry in that men's leadership aspiration may be relatively insensitive to relational identification whereas women's leadership aspiration too may be influenced by organizational identification - as per the notion that 
women have a greater tendency than men to have a communal orientation (Bakan, 1966; Donnelly \& Twenge, 2016; Eagly, 1987; Feingold, 1994; Helgeson, 1994; Lyness \& Heilman, 2006) and organizational identification inspires a communal orientation (Ashforth \& Mael, 1989; Ashforth, 2001; Ashforth, Harrison, \& Corley, 2008). Obviously, this is just speculation inspired by the current analysis, and future research putting these propositions to the test would be highly worthwhile in developing this self-construal perspective on gender and leadership aspiration.

Finally, concerning gender composition, future research may also want to assess whether the gender ratio has an impact on cooperative climate among interpersonal relationships as well as within the overall collective and eventually on leadership aspiration. Results regarding the effect of heterogeneous work groups on cooperative climate in general have been mixed. Chatman and Flynn (2001) have shown that greater team member heterogeneity, including gender, is initially associated with group norms focused on lower cooperation, yet due to greater contact between team members norms become more cooperative over time. Looking specifically at gender, it could be equally imaginable that a greater share of women is associated, right from the initial team set-up, with a more cooperative climate due to women's general tendency to be more communal (e.g., Abele 2003; Bakan, 1966; Eagly, 1987; Feingold, 1994; Helgeson, 1994), i.e., being affectionate, caring, and relationship-oriented (Gebauer et al., 2013; Lyness \& Heilman, 2006) - indeed, see Gartzia and van Knippenberg (2016). Yet, whether and how the gender ratio effects the two discussed elements of cooperative climate and eventually leadership aspiration needs to be tested and verified.

Shifting angle and looking at our results from the perspective of climate research rather than gender and leadership, we also identify some interesting take-aways. By looking at cooperative climate among important interpersonal relationships, or put differently among 
direct peers or coworkers, we answer the call for future research on "the specific impact that coworkers have in providing resources to enable their peers to successfully meet the demands of a complex work environment" (Halbesleben \& Wheeler, 2015, p. 1629). Our results show that coworker relationships are influential in women's leadership aspiration. By demonstrating the importance of this particular cooperative climate element we further extend the literature, emphasizing that a cooperative climate is particularly important for women (cf. van Emmerik, 2002, Settles, Cortina, Malley, \& Stewart, 2006).

\section{Practical Implications}

In line with our emphasis on insights that are not only of theoretical but also of practical relevance, we believe our study offers some insights for practice. These insights may be particularly beneficial if our study receives follow-up regarding more intervention-like precursors to cooperative interpersonal climate.

First and foremost, it seems wise for organizations, seeking to stimulate women's leadership aspiration to conduct a status quo assessment regarding the perceived organizational climate, assessing both cooperative interpersonal climate and cooperative collective climate, to "measure the pulse of an organization" (Roberts, Konczak, \& Macan, 2004, p. 14). To this effect, a suitable organizational climate survey should be conducted as the results of such a survey can "provide valuable information that can be used to guide the company" (Altmann, 2000, p. 65). To get representative results, it is important to not only ask people in supervisory positions because they have the tendency to assess the organizational climate more positively than regular employees (Merkys et al., 2005). Further, to create the necessary conditions for the improvement of the different cooperative climate elements, a very important step, yet only depicting a starting point, would be empower the human resource department. In a recent study Tang and Tang (2012) showed the positive impact of high-performance human resource practices (such as e.g., superior selections, trainings, 
performance appraisals and empowerment) on organizational citizenship behavior mediated by justice and service climate. Although justice and service climate are not congruent with cooperative climate, there is a certain degree of overlap, hence it is imaginable that highperformance human resource practices also feature a positive impact on cooperative organizational climate. Hence, the human resource department should use the climate survey results as a foundation to develop an encompassing roadmap how to create or improve the different cooperative climate elements, including a general code of conduct and best practices. As the organizational climate can differ between subunits (e.g., Merkys et al., 2005, Zohar \& Luria 2005), it is essential to develop subunit specific objectives, strategies, and roadmaps how to improve its cooperative interpersonal climate.

It is important to stress, that the focus should not exclusively be on improving the cooperative interpersonal climate within specific sub-units or teams, but also on rendering the organization-wide climate more cooperative. Our results show that while cooperative interpersonal climate does not per se have a positive impact on leadership aspiration (but rather just for women), cooperative collective climate features a positive impact on leadership aspiration regardless of gender. Hence, working on practical company-wide initiatives (such as e.g., overarching code of conducts or company social events) should have a positive impact on leadership aspiration for both female and male employees.

Moreover, as leadership is known to be an important factor shaping organizational climate (Grojean et al., 2004; Koene et al., 2002; Wang \& Rode, 2010), team and department leaders are likely to play a crucial role in creating an organizational climate that is conducive to leadership aspiration. As our results show, men's leadership aspiration is not significantly influenced by cooperative interpersonal climate. Currently, only one in three managers is a woman (Eurostat, 2015). Therefore, it might be particularly important to provide respective trainings on how to create a cooperative interpersonal climate directed towards managers, so 
that they are aware of how to create and constantly work on improving an environment stimulating female leadership aspiration. In addition to being trained on working towards a cooperative organizational climate, leaders as well as management should be held accountable for metrics measuring employee perceptions of cooperative collective climate and cooperative interpersonal climate. To that effect it may be helpful to introduce different key performance indicators (KPI), measuring both types of climates for the assessment of team and department leaders as well as management alike. However, as the two discussed elements of cooperative climate are not only something to be "enforced" by supervisors or management, also the behavior of employees and their positive or negative impact on the two cooperative climate concepts should be observed, evaluated and, if feasible, constitute part of the year-end assessment.

\section{Limitations and Directions for Future Research}

Our study possesses some limitations that have to be mentioned. To begin with, this study is correlational and thus it is impossible to draw conclusions about causality. Although we would argue that the observed relationships also make sense from the perspective of a conceptual causal model in which climate has a gender-contingent causal effect on leadership aspiration, data from field-experiments is necessary to be able to draw conclusions about causality.

Moreover, our study could be criticized for common method bias. To ensure that such bias does not constitute a shortcoming of our study, we conducted, as suggested by one of our anonymous reviewers, the Harman's one-factor test according to Podsakoff, MacKenzie, and Podsakoff (2012). As the variance explained by one factor is $36.96 \%$, hence below $50 \%$, common method bias does not seem to be an issue for our results. In this respect, it is also important to note, however, that common method bias is a concern for main effects and not for interactions (McClelland and Judd, 1993) and moreover is a concern primarily for percept- 
percept relationships and not for relationships with a factual variable like gender. That is common method variance is potential concern for the climate-aspiration relationships (but see the Harman test results), but not for the gender x climate interaction that is core to our study.

It is also relevant to note that we did not measure the self-construals of men and women to further substantiate our analysis in terms of dispositions towards relational (women) versus collective (men) self-construal. Rather, as many researchers do, we used gender as a proxy. Clearly, future research can further bolster our conclusions by explicitly measuring the presumed different interdependent self-construals.

Moreover, even when a strength of our study is that it draws on respondents from many different organizations (i.e., conceptually we are interested in between-organization variation), in practice this meant that we relied on measures of psychological climate (i.e., individual level perceptions) and could not determine whether these perceptions where shared within the same organization. To complement the current findings then it would be good to get a more encompassing view of the distinct elements of cooperative climate within an organization by surveying various members from the same organization because employees do not necessarily agree when classifying the degree of cooperation within an organization (Bogaert et al., 2012).

In addition, it would be interesting for future research to assess more objective outcomes than leadership aspiration, i.e. leadership attainment. Despite the fact that leadership attainment is clearly associated with leadership aspiration (Schoon et al., 2007; Schoon \& Polek, 2001; Tharenou, 2001), the one should not be assumed from the other. It is very likely that also other factors apart from leadership aspiration play a role in leadership attainment. It seems to be conceivable that even if women and men report similar leadership aspiration levels, that women still have more difficulty in actually receiving a leadership position. Also, as we conducted our study within the UK, a Western context, it would hence be 
an interesting avenue of future research to replicate the study in a non-Western context. As Western men and women differ the most with regards to their responsiveness to different selfconstruals (Guimond, 2008; Cross \& Madson, 1997), it would be interesting to assess whether the gender differences in leadership aspiration associated with cooperative interpersonal climate and cooperative collective climate persist.

\section{Conclusion}

Our findings provide a step towards comprehending how cooperative climate among close relationships, speaking to the greater female disposure to a relationship oriented selfconstrual, influences women's leadership aspiration more than men's. In contrast cooperative collective climate, emphasizing the organization as a whole and as such mapping to the greater disposure of men to have a collective self-construal, influences men's leadership aspiration more than women. These results point to promising avenues for future research and relevant implications for practitioners alike striving for increasing women's leadership aspiration. 


\section{References}

Abele, A. E. (2003). The dynamics of masculine-agentic and feminine-communal traits: findings from a prospective study. Journal of Personality and Social Psychology, 85, 768-776.

Adler, P. S., \& Kwon, S. W. (2002). Social capital: Prospects for a new concept. Academy of management review, 27, 17-40.

Aiken, L. S., \& West, S. G. (1991). Multiple regression: Testing and interpreting interactions. Thousand Oaks, CA: Sage.

Altmann, R. (2000). Forecasting your organizational climate. Journal of Property Management, 65, 62-67.

Arnold, T., Flaherty, K. E., Voss, K. E., \& Mowen, J. C. (2009). Role stressors and retail performance: The role of perceived competitive climate. Journal of Retailing, 85, 194205.

Athey, S., Avery, C., \& Zemsky, P. (2000). Mentoring and diversity. American Economic Review, 765-786.

Arora, N., Nuseir, M. T., Nusair, T. T., \& Arora, R. (2012). Study-based moderators influencing the relationship between organizational climate and employee's organization commitment: A meta-analysis. EuroMed Journal of Business, 7, 201-220.

Ashforth, B. (2001), Role transitions in organizational life: An identity-based perspective. Malwah, NJ: Routledg.

Ashforth, B. E., \& Mael, F. (1989), Social identity theory and the organization, Academy of Management Review, 14, 20-39.

Ashforth, B. E., Harrison, S. H., \& Corley, K. G. (2008), Identification in organizations: An examination of four fundamental questions, Journal of Management, 34, 325-374. 
Bakan, D. (1966). The Duality of human existence. Chicago, IL: Rand McNally.

Basford, T. E., \& Offermann, L. R. (2012). Beyond leadership: The impact of coworker relationships on employee motivation and intent to stay. Journal of Management \& Organization, 18, 807-817.

Bass, B. M., \& Stogdill, R. M. (1990). Bass \& Stogdill's handbook of leadership: Theory, research, and managerial applications. New, NY: Free Press.

Baumeister, R. F., \& Sommer, K. L. (1997). What do men want? Gender differences and two spheres of belongingness: Comment on Cross and Madson (1997). Psychological Bulletin, 122 , 38-44.

Bogaert, S., Boone, C., \& Van Witteloostuijn, A. (2012). Social value orientation and climate strength as moderators of the impact of work group cooperative climate on affective commitment. Journal of Management Studies, 49, 918-944.

Brown, S. P., \& Leigh, T. W. (1996). A new look at psychological climate and its relationship to job involvement, effort, and performance. Journal of applied psychology, 81, 358368.

Burns, J. M. (1978). Leadership. New York, NY: Harper \& Row.

Carli, L. L., Alawa, L., Lee, Y., Zhao, B., \& Kim, E. (2016), Stereotypes About Gender and Science Women $\neq$ Scientists, Psychology of Women Quarterly, 1, 1-17.

Carli, L. L, \& Eagly, A. H. (2016), Women face a labyrinth: an examination of metaphors for women leaders, Gender in Management: An International Journal, 31, 514-527.

Carr, J. Z., Schmidt, A. M., Ford, J. K., \& DeShon, R. P. (2003). Climate perceptions matter: a meta-analytic path analysis relating molar climate, cognitive and affective states, and individual level work outcomes. Journal of Applied Psychology, 88, 605-619.

Chan, K.-Y. \& Drasgow, F. (2001). Toward a theory of individual differences and leadership: Understanding the motivation to lead. Journal of Applied Psychology, 86, 481-598. 
Chatman, J. A., \& Flynn, F. J. (2001). The influence of demographic heterogeneity on the emergence and consequences of cooperative norms in work teams. Academy of Management Journal, 44, 956-974.

Chen, C. J., \& Huang, J. W. (2007). How organizational climate and structure affect knowledge management-The social interaction perspective. International Journal of Information Management, 27, 104-118.

Chiaburu, D. S., \& Harrison, D. A. (2008). Do peers make the place? Conceptual synthesis and meta-analysis of coworker effects on perceptions, attitudes, OCBs, and performance. Journal of Applied Psychology, 93, 1082-1103.

Coda, R., da Silva, D., \& Custodio, I. (2015). Multidimensional configurations of the organizational climate construct. The International Journal of Human Resource Management, 26, 1827-1847.

Cross, S. E., Bacon, P. L., \& Morris, M. L. (2000). The relational-interdependent selfconstrual and relationships. Journal of personality and social psychology, 78, 791-808.

Cross, S. E., \& Madson, L. (1997). Models of the self: self-construals and gender. Psychological bulletin, 122, 5-37.

Day, R., \& Allen, T. D. (2004). The relationship between career motivation and self-efficacy with protégé career success. Journal of Vocational Behavior, 64, 72-91.

De Dreu, C. K. W., Nijstad, B. A., \& van Knippenberg, D. (2008). Motivated information processing in group judgment and decision making. Personality and Social Psychology Review, 12, 22-49.

Denison, D. R. (1996). What is the difference between organizational culture and organizational climate? A native's point of view on a decade of paradigm wars. Academy of management review, 21, 619-654. 
Inventory, 1993-2012: a Cross-Temporal Meta-Analysis, Sex Roles, 2, 1-10.

Knudsen, H. K., Ducharme, L. J., \& Roman, P. M. (2008). Clinical supervision, emotional exhaustion, and turnover intention: A study of substance abuse treatment counselors in the Clinical Trials Network of the National Institute on Drug Abuse. Journal of substance abuse treatment, 35, 387-395.

Ducharme, L. J., \& Martin, J. K. (2000). Unrewarding work, coworker support, and job satisfaction a test of the Buffering Hypothesis. Work and Occupations, 27: 2, 223-243.

Eagly, A. H. (1987). Sex differences in social behavior: A social-role interpretation. Hillsdale, NJ: Erlabum.

Eagly, A. H., \& Carli, L. L. (2003). The female leadership advantage: An evaluation of the evidence. The leadership quarterly, 14, 807-834.

Eagly, A. H., \& Carli, L. L. (2007). Through the labyrinth. Boston, MA: Harvard Business School Press.

Eagly, A. H., \& Karau, S. J. (2002). Role congruity theory of prejudice toward female leaders. Psychological review, 109, 573-598.

Eagly, A. H., Karau, S. J., Miner, J. B., \& Johnson, B. T. (1994). Gender and motivation to manage in hierarchic organizations: A meta-analysis. The Leadership Quarterly, 5, 135159.

European Commission (2015). Board members. Retrieved from: http://ec.europa.eu/justice/gender-equality/gender-decision-making/database/businessfinance/supervisory-board-board-directors/index_en.htm

Eurostat (2014). Erwerbstätigenquote der Gesamtbevölkerung, Männer und Frauen, in der Altersgruppe der 20-64-Jährigen. Retrieved from: http://ec.europa.eu/eurostat/tgm/refreshTableAction.do?tab=table \&plugin=1\&pcode=tes em010\&language $=$ de 
Eurostat (2015). Women earned on average 16\% less than men in 2013 in the EU. Retrieved from:

https://www.google.nl/url?sa=t\&rct=j\&q=\&esrc=s\&source=web\&cd=1\&ved=0CCIQFjA AahUKEwjf5bTVruzHAhWCfhoKHRKRALY\&url=http\%3A\%2F\%2Fec.europa.eu\%2F eurostat\%2Fdocuments\%2F2995521\%2F6729998\%2F3-05032015-APEN.pdf\&usg=AFQjCNFgULQE9EaMEBErmSO3K4tOodX5vg\&cad=rja

Evans, J. R., \& Mathur, A. (2005). The value of online surveys. Internet research, 15, 195219.

Feingold, A. (1994). Gender differences in personality: a meta-analysis. Psychological bulletin, 116, 429-456.

Ferris, G. R., \& Mitchell, T. R. (1987). The components of social influence and their importance for human resources research. Research in personnel and human resources management, 5, 103-128.

Fisher, D. M. (2014). A multilevel cross-cultural examination of role overload and organizational commitment: Investigating the interactive effects of context. Journal of Applied Psychology, 99, 723-736.

Fletcher, T. D., \& Nusbaum, D. N. (2009). Development of the competitive work environment scale: A multidimensional climate construct. Educational and Psychological Measurement, 20, 1-20.

Gabriel, S., \& Gardner, W. L. (1999). Are there" his" and" hers" types of interdependence? The implications of gender differences in collective versus relational interdependence for affect, behavior, and cognition. Journal of personality and social psychology, 77, 642-655.

Gartzia, L., \& van Knippenberg, D. (2016). Too masculine, too bad: Effects of communion on leaders' promotion of cooperation. Group \& Organization Management, 41, 458-490. 
Gbadamosi, G., Evans, C., Richardson, M., \& Ridolfo, M. (2015). Employability and students' part-time work in the UK: does self-efficacy and career aspiration matter?. British Educational Research Journal, 41, 1086-1107.

Gebauer, J. E., Paulhus, D. L., \& Neberich, W. (2013). Big two personality and religiosity across cultures: Communals as religious conformists and agentics as religious contrarians. Social Psychological and Personality Science, 4, 21-30.

Grant, A. M. (2007). Relational job design and the motivation to make a prosocial difference. Academy of Management Review, 32, 393-417.

Grant, A. M. (2009), Putting self-interest out of business? Contributions and unanswered questions from use-inspired research on prosocial motivation, Industrial and Organizational Psychology, 2, 94 - 98.

Grant, A. M., \& Berry, J. W. (2011). The necessity of others is the mother of invention: Intrinsic and prosocial motivations, perspective taking, and creativity. Academy of Management Journal, 54, 73-96.

Gray, M. P., \& O'Brien, K. M. (2007). Advancing the assessment of women's career choices: The Career Aspiration Scale. Journal of Career Assessment, 15, 317-337.

Grojean, M. W., Resick, C. J., Dickson, M. W., \& Smith, D. B. (2004). Leaders, values, and organizational climate: Examining leadership strategies for establishing an organizational climate regarding ethics. Journal of business ethics, 55, 223-241.

Guimond, S. (2008). Psychological similarities and differences between women and men across cultures. Social and Personality Psychology Compass, 2, 494-510.

Halbesleben, J. R., \& Wheeler, A. R. (2015). To invest or not? The role of coworker support and trust in daily reciprocal gain spirals of helping behavior. Journal of Management, $41,1628-1650$.

Hammami, H., Amara, N., \& Landry, R. (2013). Organizational climate and its influence on 
brokers' knowledge transfer activities: A structural equation modeling. International Journal of Information Management, 33, 105-118.

Helgeson, V. S. (1994). Relation of agency and communion to well-being: Evidence and potential explanations. Psychological bulletin, 116, 412-428.

Hoobler, J. M., Lemmon, G., \& Wayne, S. J. (2014). Women's Managerial Aspirations An Organizational Development Perspective. Journal of Management, 40, 703-730.

Hoyt, C. L. (2013). Inspirational or Self-Deflating The Role of Self-Efficacy in Elite Role Model Effectiveness. Social Psychological and Personality Science, 4, 290-298.

Janz, B. D., \& Prasarnphanich, P. (2003). Understanding the antecedents of effective knowledge management: the importance of a knowledge-centered culture. Decision sciences, $34,351-384$.

Killeen, L. A., López-Zafra, E., \& Eagly, A. H. (2006). Envisioning oneself as a leader: Comparisons of women and men in Spain and the United States. Psychology of Women Quarterly, 30, 312-322.

Koene, B. A., Vogelaar, A. L., \& Soeters, J. L. (2002). Leadership effects on organizational climate and financial performance: Local leadership effect in chain organizations. The Leadership Quarterly, 13, 193-215.

Koenig, A. M., Eagly, A. H., Mitchell, A. A., \& Ristikari, T. (2011). Are leader stereotypes masculine? A meta-analysis of three research paradigms. Psychological bulletin, 137, 616-642.

Kohn, A. (1992). No contest: The case against competition. Houghton Mifflin Harcourt.

Konrad, A. M., Ritchie Jr, J. E., Lieb, P., \& Corrigall, E. (2000). Sex differences and similarities in job attribute preferences: a meta-analysis. Psychological bulletin, 126, 593641.

Koys, D. J., \& DeCotiis, T. A. (1991). Inductive measures of psychological climate. Human 
Relations, 44, 265-285.

Kuvaas, B., \& Dysvik, A. (2010). Permanent employee investment and social exchange and psychological cooperative climate among temporary employees. Economic and Industrial Democracy, 20, 1-23.

Lips, H. M. (2000). College students' visions of power and possibility as moderated by gender. Psychology of Women Quarterly, 24, 39-43.

Lips, H. M. (2001). Envisioning positions of leadership: The expectations of university students in Virginia and Puerto Rico. Journal of Social Issues, 57, 799-813.

Llopis Córcoles, Ó., \& Foss, N. J. (2012). Does a cooperative climate always leads to knowledge sharing? The roles of intrinsic motivation and job autonomy. OLKC 2012 Conference. Valencia (Spain)

London, M. (1993). Relationships between career motivation, empowerment and support for career development. Journal of Occupational and Organizational Psychology, 66, 5569.

Lyness, K. S. \& Heilman, M. E. (2006). When fit is fundamental: Performance evaluations and promotions of upper-level female and male managers. Journal of Applied Psychology, 91, 777-785.

Lyness, K. S., \& Thompson, D. E. (2000). Climbing the corporate ladder: Do female and male executives follow the same route? Journal of Applied Psychology, 85, 86-101.

Mael, F. \& Ashforth, B. E. (1992). Alumni and their alma mater: A partial test of the reformulated model of organizational identification. Journal of Organizational Behavior, 13, 103-123.

McGuire, G. M., (2000). Gender, race, ethnicity, and networks: the factors affecting the status of employees' network members. Work And Occupations, 27, 500-523.

Merkys, G., Kalinauskaitė, R., Beniušienė, I., Vveinhardt, J., \& Dromantas, M. (2005). 
Organisational climate test for Lithuania work organisations: validation and correlation with teamwork test. Social Sciences, 3, 39-51.

Moran, E. T., \& Volkwein, J. F. (1992). The cultural approach to the formation of organizational climate. Human relations, 45, 19-47.

Morrison, A. M., White, R. P., \& Velsor, E. V. (1987). Breaking the glass ceiling. Reading. MA: Addison-Wesley.

Murphy, S. E. (1992). The contribution of leadership experience and self-efficacy to group performance under evaluation apprehension (Doctoral dissertation). Retrieved from: https://digital.lib.washington.edu/researchworks/handle/1773/9167

Noe, R. A., Noe, A. W., \& Bachhuber, J. A. (1990). An investigation of the correlates of career motivation. Journal of Vocational Behavior, 37, 340-356.

Oakley, J. G. (2000). Gender-based barriers to senior management positions: Understanding the scarcity of female CEOs. Journal of business ethics, 27, 321-334.

Podsakoff, P. M., MacKenzie, S. B., \& Podsakoff, N. P. (2012). Sources of method bias in social science research and recommendations on how to control it. Annual review of psychology, 63, 539-569.

Patterson, M. G., West, M. A., Shackleton, V. J., Dawson, J. F., Lawthom, R., Maitlis, S., Robinson, D., \& Wallace, A. M. (2005). Validating the organizational climate measure: links to managerial practices, productivity and innovation. Journal of organizational behavior, 26, 379-408.

Ragins, B. R., \& Cotton, J. L. (1991). Easier said than done: Gender differences in perceived barriers to gaining a mentor. Academy of Management Journal, 34, 939-951.

Regts, G., \& Molleman, E. (2013). To leave or not to leave: When receiving interpersonal citizenship behavior influences an employee's turnover intention. Human relations, 66, 193-218. 
Roberts, L. L., Konczak, L. J., \& Macan, T. H. (2004). Effects of data collection method on organizational climate survey results. Applied HRM Research, 9, 13-26.

Rudman, L. A., \& Glick, P. (2001), Prescriptive gender stereotypes and backlash toward agentic women, Journal of social issues, 57, 743-762.

Rudman, L. A., \& Phelan, J. E. (2010). The effect of priming gender roles on women's implicit gender beliefs and career aspirations. Social Psychology, 41, 192-202.

Sahadev, S., Seshanna, S., \& Purani, K. (2014). Effects of competitive psychological climate, work-family conflict and role conflict on customer orientation: The case of call center employees in India. Journal of Indian Business Research, 6, 70-84.

Savery, L. K. (1990). Men and women in the workplace: Evidence of occupational differences. Leadership \& Organization Development Journal, 11, 13-16.

Schneider, B., Ehrhart, M. G., \& Macey, W. H. (2013). Organizational climate and culture. Annual review of psychology, 64, 361-388.

Schoon, I., Polek, E. (2011). Teenage career aspirations and adult career attainment: The role of gender, social background and general cognitive ability. International Journal of Behavioral Development, 35, 210-217.

Schoon, I., Martin, P., \& Ross, A. (2007). Career transitions in times of social change. His and her story. Journal of Vocational Behavior, 70, 78-96.

Settles, I. H., Cortina, L. M., Malley, J., \& Stewart, A. J. (2006). The climate for women in academic science: The good, the bad, and the changeable. Psychology of Women Quarterly, 30, 47-58.

Simon, L. S., Judge, T. A., \& Halvorsen-Ganepola, M. D. (2010). In good company? A multistudy, multi-level investigation of the effects of coworker relationships on employee well-being. Journal of Vocational Behavior, 76, 534-546.

Singer, M. (1991). The Relationship Between Employee Sex, Length of Service and 
Leadership Aspirations: A Study from Valence, Self-Efficacy and Attribution Perspectives. Applied Psychology, 40, 417-436.

Tang, T. W., \& Tang, Y. Y. (2012). Promoting service-oriented organizational citizenship behaviors in hotels: The role of high-performance human resource practices and organizational social climates. International Journal of Hospitality Management, 31, 885-895.

Tharenou, P. (2001). Going up? Do traits and informal social processes predict advancing in management? Academy of Management Journal, 44, 1005-1017.

Tharenou, P., \& Terry, D. J. (1998). Reliability and Validity of Scores on Scales to Measure Managerial Aspirations. Educational and Psychological Measurement, 58, 475-492.

Thumin, F. J., \& Thumin, L. J. (2011). The measurement and interpretation of organizational climate. The Journal of psychology, 145, 93-109.

Tsai, C. Y., Horng, J. S., Liu, C. H., \& Hu, D. C. (2015). Work environment and atmosphere: The role of organizational support in the creativity performance of tourism and hospitality organizations. International Journal of Hospitality Management, 46, 26-35. UN (2015). International Standard Industrial Classifications of all economic activities. Retrieved from: http://unstats.un.org/unsd/cr/registry/regcst.asp?Cl=27\&Lg=1\&Top=1 van Emmerik, I. H. (2002). Gender differences in the effects of coping assistance on the reduction of burnout in academic staff. Work \& Stress, 16, 251-263.

van Knippenberg, D., van Knippenberg, B., De Cremer, D., \& Hogg, M. A. (2004). Leadership, self, and identity: A review and research agenda. The Leadership Quarterly, $15,825-856$.

van Knippenberg, D., \& van Schie, E. C. M. (2000). Foci and correlates of organizational identification. Journal of Occupational and Organizational Psychology, 73, 137-147. Wang, P., \& Rode, J. C. (2010). Transformational leadership and follower creativity: The 
moderating effects of identification with leader and organizational climate. Human relations, $63,1105-1128$.

Yeagley, E. E., Subich, L. M., \& Tokar, D. M. (2010). Modeling college women's perceptions of elite leadership positions with Social Cognitive Career Theory. Journal of Vocational Behavior, 77, 30-38.

Zohar, D., \& Luria, G. (2005). A multilevel model of safety climate: cross-level relationships between organization and group-level climates. Journal of Applied Psychology, 90, 616628. 


\section{Table 1}

Descriptive statistics and correlations

\begin{tabular}{|c|c|c|c|c|c|c|c|c|}
\hline & Mean & SD & 1 & 2 & 3 & 4 & 5 & 6 \\
\hline 1. Leadership aspiration & 2.85 & .91 & $(.96)$ & & & & & \\
\hline 2. Gender & $\mathrm{n} / \mathrm{a}$ & $\mathrm{n} / \mathrm{a}$ & -.10 & & & & & \\
\hline 3. Cooperative interpersonal climate & 3.69 & .79 & $.34 * *$ & .05 & $(.91)$ & & & \\
\hline 4. Cooperative collective climate & 3.21 & .95 & $.37 * *$ & -.01 & $.56 * *$ & $(.88)$ & & \\
\hline 5. Efficacy & 3.45 & .68 & $.49 * *$ & $-.11 *$ & $.20 * *$ & $.13 * *$ & $(.86)$ & \\
\hline 6. Hierarchical level & $\mathrm{n} / \mathrm{a}$ & & $.23 * *$ & -.09 & .02 & .09 & $.19 * *$ & \\
\hline 7. Female targets & & & $.29 * *$ & -.06 & $.16^{* *}$ & .05 & .09 & .07 \\
\hline
\end{tabular}

Note. Gender ( $1=$ female; $0=$ male $)$, hierarchical level $(1=$ lower/middle manager; $0=$ other $)$ and female targets $(1=y e s, 0=$ no $)$ are dummy-coded variables. Coefficients alpha for each scale are given in parentheses on the diagonal.

${ }^{*} p<.05^{* *} p<.01$ 
Table 2

Regression Results for Leadership Aspiration

\begin{tabular}{|c|c|c|c|c|c|}
\hline Predictor & $b$ & $S E$ & $\beta$ & $t$ & $p$ \\
\hline \multicolumn{6}{|l|}{$\overline{\text { Step } 1}$} \\
\hline Constant & 0.63 & 0.20 & & 3.25 & .001 \\
\hline Efficacy & 0.60 & 0.06 & .40 & 10.63 & .000 \\
\hline Hierarchical level & 0.27 & 0.09 & .13 & 3.05 & .002 \\
\hline Female targets & 0.68 & 0.12 & .24 & 5.88 & .000 \\
\hline \multicolumn{6}{|l|}{ Step 2} \\
\hline Constant & 0.89 & 0.19 & & 4.60 & .000 \\
\hline Efficacy & 0.54 & 0.05 & .40 & 9.94 & .000 \\
\hline Hierarchical level & 0.24 & 0.08 & .11 & 2.85 & .005 \\
\hline Female targets & 0.62 & 0.11 & .22 & 5.62 & .000 \\
\hline Female & -0.06 & 0.07 & -.03 & -0.80 & .427 \\
\hline $\begin{array}{l}\text { Cooperative interpersonal } \\
\text { climate }\end{array}$ & 0.10 & 0.06 & .09 & 1.78 & .076 \\
\hline $\begin{array}{l}\text { Cooperative collective } \\
\text { climate }\end{array}$ & 0.24 & 0.05 & .25 & 5.29 & .000 \\
\hline \multicolumn{6}{|l|}{ Step 3} \\
\hline Constant & 0.88 & 0.19 & & 4.56 & .000 \\
\hline Efficacy & 0.54 & 0.05 & .40 & 9.99 & .000 \\
\hline Hierarchical level & 0.24 & 0.08 & .11 & 2.84 & .005 \\
\hline Female targets & 0.66 & 0.11 & .23 & 5.93 & .000 \\
\hline Female & -0.05 & 0.07 & -.03 & -0.77 & .443 \\
\hline $\begin{array}{l}\text { Cooperative interpersonal } \\
\text { climate }\end{array}$ & -0.02 & 0.08 & -.02 & -0.22 & .825 \\
\hline $\begin{array}{l}\text { Cooperative collective } \\
\text { climate }\end{array}$ & 0.34 & 0.06 & .35 & 5.32 & .000 \\
\hline $\begin{array}{l}\text { Gender x coop. } \\
\text { interpersonal climate }\end{array}$ & 0.21 & 0.11 & .13 & 1.97 & .049 \\
\hline $\begin{array}{l}\text { Gender x coop. collective } \\
\text { climate }\end{array}$ & -0.20 & 0.09 & -.15 & -2.23 & .026 \\
\hline
\end{tabular}




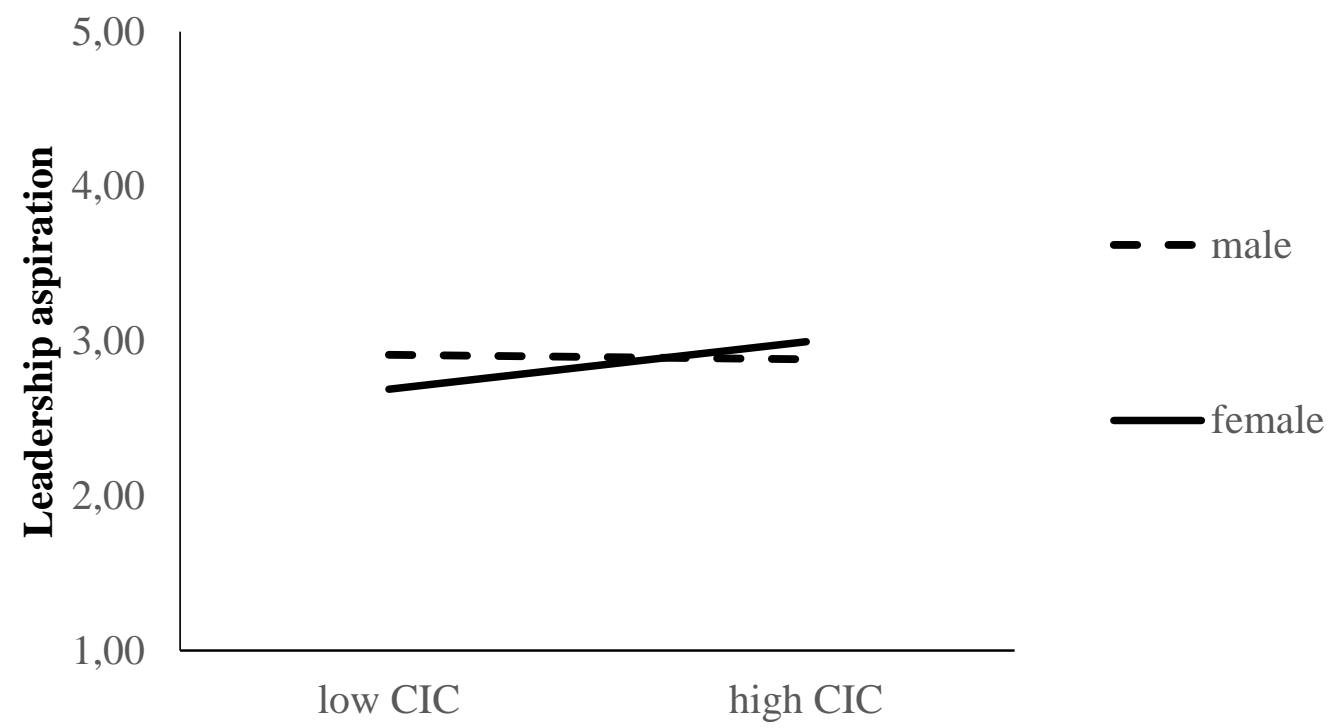

Figure 1. Simple slope analysis of leadership aspiration: impact of cooperative interpersonal climate (CIC) 


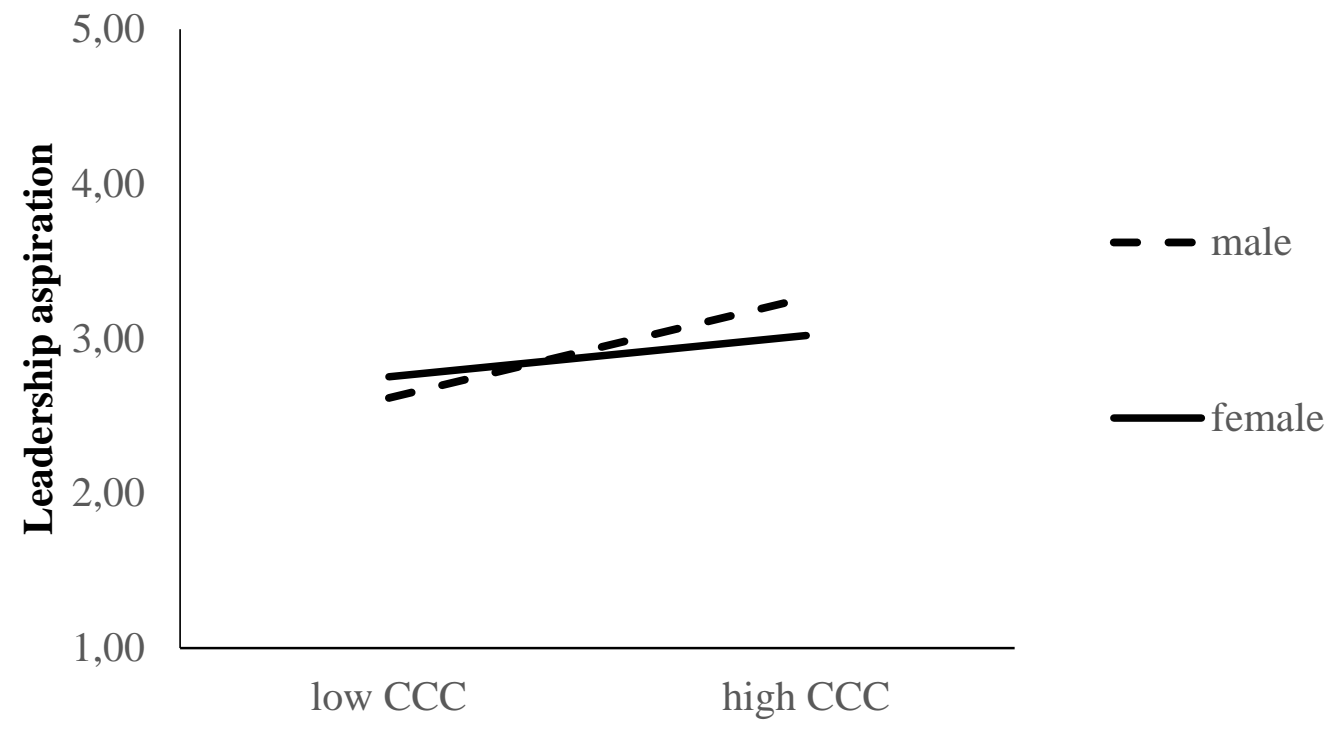

Figure 2. Simple slope analysis of leadership aspiration: impact of cooperative collective climate (CCC) 
Appendix

Gender differences in demographics and control variables

\begin{tabular}{|c|c|c|c|c|c|c|}
\hline & \multicolumn{3}{|c|}{ Women } & \multicolumn{3}{|c|}{ Men } \\
\hline & Mean & $\mathrm{SD}$ & $\%$ & Mean & SD & $\%$ \\
\hline \multicolumn{7}{|l|}{ Demographics } \\
\hline Age & 42.51 & 10.76 & & 47.34 & 9.60 & \\
\hline Work experience & 20.89 & 11.39 & & 26.64 & 11.23 & \\
\hline Organizational experience & 9.73 & 7.59 & & 13.46 & 9.41 & \\
\hline Job experience & 6.93 & 5.90 & & 8.97 & 7.79 & \\
\hline \multicolumn{7}{|l|}{ Hierarchical position } \\
\hline Non-supervisor & & & $55.9 \%$ & & & $42.6 \%$ \\
\hline First level management & & & $18.8 \%$ & & & $18.3 \%$ \\
\hline Middle management & & & $19.8 \%$ & & & $27.2 \%$ \\
\hline Upper management & & & $3.0 \%$ & & & $9.4 \%$ \\
\hline Executive management & & & $2.5 \%$ & & & $2.5 \%$ \\
\hline \multicolumn{7}{|l|}{ Educational background } \\
\hline High-school & & & $26.2 \%$ & & & $29.2 \%$ \\
\hline Apprenticeship & & & $22.3 \%$ & & & $21.3 \%$ \\
\hline Bachelor & & & $35.6 \%$ & & & $34.2 \%$ \\
\hline Master & & & $15.8 \%$ & & & $15.3 \%$ \\
\hline \multicolumn{7}{|l|}{ Cultural background } \\
\hline British & & & $89.1 \%$ & & & $92.6 \%$ \\
\hline Continental European & & & $5.0 \%$ & & & $3.5 \%$ \\
\hline American & & & $1.0 \%$ & & & $0.5 \%$ \\
\hline African & & & $1.0 \%$ & & & $2.0 \%$ \\
\hline Asian & & & $3.5 \%$ & & & $0.5 \%$ \\
\hline Australian & & & $0.5 \%$ & & & $1.0 \%$ \\
\hline \multicolumn{7}{|l|}{ Family background } \\
\hline Single & & & $26.2 \%$ & & & $29.2 \%$ \\
\hline In a relationship & & & $28.7 \%$ & & & $14.4 \%$ \\
\hline Married & & & $45.0 \%$ & & & $56.4 \%$ \\
\hline Children & & & $52.5 \%$ & & & $65.8 \%$ \\
\hline \multicolumn{7}{|l|}{ Control variables } \\
\hline Leadership self-efficacy & 3.37 & 0.68 & & 3.52 & 0.67 & \\
\hline Female targets & & & $9.9 \%$ & & & $13.9 \%$ \\
\hline
\end{tabular}

Note. Female targets $(1=$ yes, $0=$ no $)$ is a dummy-coded variables. 
Measurements

Measurements

Leadership aspiration (5-point scale, $1=$ strongly disagree to $5=$ strongly agree)

Please indicate to which extent you agree with each statement:

(1) I hope to become a leader in my career field.

(2) When I am established in my career, I would like to manage other employees.

(3) I do not plan on devoting energy to getting promoted in the organization or business I am working in. (reverse)

(4) When I am established in my career, I would like to train others.

(5) I hope to move up through any organization or business I work in.

(6) Attaining leadership status in my career is not that important to me. (reverse)

(7) I would like to obtain a (higher) leadership position.

(8) I would like to be in a position of greater responsibility and influence in my department/organization.

(9) My aspirations are very high in regard to professional recognition and achievement.

(10) I have sought feedback on my job performance.

(11) I have discussed my career prospects with someone with more experience in the department/organization.

(12) I have engaged in career path planning.

(13) I have updated my skills in order to be more competitive for promotion.

(14) I have discussed my aspirations with a senior person in the department/organization.

(15) I have volunteered for activities other than my day-to-day work tasks, such as working parties and selection panels.

(16) I have volunteered for important assignments with the intent of helping to further my advancement possibilities.

(17) I have requested to be considered for promotions.

Cooperative interpersonal climate $(5$-point scale, $1=$ strongly disagree to $5=$ strongly agree)

Please indicate to which extent you agree with each statement:

(1) In the company I work for people pitch in to help each other out.

(2) In the company I work for people tend to get along with each other.

(3) In the company I work for people take personal interest in one another.

(4) There is a lot of team spirit among people working for this company.

(5) I feel that I have a lot in common with the other people working for the same company as me.

Cooperative collective climate $(5$-point scale, $1=$ strongly disagree to $5=$ strongly agree)

Please indicate to which extent you agree with each statement:

(1) This company pays little attention to the interest of employees (reverse).

(2) This company tries to look after its employees.

(3) This company cares about its employees.

(4) This company tries to be fair in actions towards employees. 
Leadership self-efficacy (5-point scale, $1=$ strongly disagree to $5=$ strongly agree) see below)

Please indicate to which extent you agree with each statement:

(1) I know a lot more than most people about what it takes to be a good leader

(2) I know what it takes to make a group accomplish its task.

(3) In general, I am not very good at leading a group of my peers. (reverse)

(4) I am confident of my ability to influence a group I lead.

(5) I have no idea what it takes to keep a group running smoothly. (reverse)

(6) I know how to encourage good group performance.

(7) I am able to allow most group members to contribute to the task when leading a group.

(8) Overall, I doubt that I could lead a group successfully. (reverse)

Note. Leadership aspiration scale adapted from Gray and O’Brien (2007); Tharenou and Terry (1998); Day and Allen (2004), being itself adapted from London (1993) and Noe et al. (1990). Cooperative interpersonal scale developed by Koys \& DeCotiis (1991) as "cohesion climate". Cooperative collective scale developed by Patterson et al. (2005) as “welfare scale” Leadership self-efficacy scale developed by Murphy (1992). 